\title{
Device Damaged by another Device
}

National Cancer Institute

\section{Source}

National Cancer Institute. Device Damaged by another Device. NCI Thesaurus. Code C62951.

Problem associated with one device causing harm to another device. 